\title{
Ecological variability of high elevation forests in central British Columbia ${ }^{1}$
}

\author{
by Craig DeLong ${ }^{2}$ and Del Meidinger ${ }^{3}$
}

\begin{abstract}
High-elevation, late-successional forests over much of British Columbia are dominated by Engelmann spruce (Picea engelmannii Parry ex. Engelm.) and subalpine fir (Abies lasiocarpa (Hook.) Nutt.). Throughout the range of these forests, however, there is a wide variation in natural disturbance and successional dynamics as influenced by diverse climate and topography. We divided these high elevation forests into four groups arranged along a regional climatic gradient that affects forest composition, structure and disturbance regime. For each, we describe the climate, topography, major vegetation, and natural disturbance dynamics. We suggest that management practices reflect the ecological variability demonstrated for these high elevation forests.
\end{abstract}

Keywords: high elevation forests, ecological variability, natural disturbance dynamics, vegetation, Engelmann spruce, subalpine fir, British Columbia, climate, topography

Les forêts de hautes altitudes et de fin de succession pour l'ensemble de la Colombie-Britannique sont dominées par l'épinette d'Engelmann (Picea engelmannii Parry ex. Engelm.) et par le sapin subalpin (Abies lasiocarpa (Hook.) Nutt.). Au sein de la distribution de ces forêts, il existe cependant une grande variation dans les dynamiques de perturbation naturelle et de succession découlant des climats variés et de la topographie. Nous avons divisé ces forêts de haute altitude en quatre groupes selon un gradient climatique régional qui affecte la composition forestière, la structure et le régime de perturbation. Pour chacun de ces groupes, nous décrivons le climat, la topographie, les principaux végétaux et la dynamique des perturbations naturelles. Nous suggérons que les pratiques d'aménagement reflètent la variabilité écologique démontrée pour ces forêts de haute altitude.

Mots-clés : forêts de haute altitude, variabilité écologique, dynamique des perturbations naturelles, végétation, épinette d'Engelmann, sapin subalpin, Colombie-Britannique, climat, topographie

\section{Introduction}

Late-successional forests dominated by Engelmann spruce (Picea engelmannii Parry ex. Engelm.) and subalpine fir (Abies lasiocarpa (Hook.) Nutt.) are widespread at high elevation over a large portion of British Columbia. Classified by the Biogeoclimatic Ecosystem Classification system (Pojar et al. 1987) as belonging in the Engelmann Spruce - Subalpine Fir (ESSF) Zone (Meidinger and Pojar 1991), they cover approximately 14.2 million ha of land in B.C. This compares to the other high elevation forest zones, the Spruce - Willow Birch Zone and the Mountain Hemlock Zone, which cover 3.5 and 7.2 million ha, respectively.

Although the tree species composition and structure of old forests is similar and the climate is relatively cold over the geographic extent of the ESSF zone, there is a wide range in the climatic regime that results in differences in regeneration, natural disturbance dynamics, successional and vegetation patterns. This range in climate is reflected in the 17 forested biogeoclimatic subzones currently described for the zone in B.C. (Coupé et al. 1991, Steen and Coupé 1997, Braumandl and Eng 2002). In this paper, we illustrate the climatic variation in the zone and its influence on forest dynamics, and management decision-making.

${ }^{1}$ Paper presented at "Mountain Forests: Conservation and Management," IUFRO Silviculture Conference, Vernon, British Columbia, Canada, July 28-August $1,2002$.

${ }^{2}$ B.C. Ministry of Forests, $10114^{\text {th }}$ Ave., Prince George, B.C. V2L 3H9. Email: Craig.Delong@gems1.gov.bc.ca

${ }^{3}$ B.C. Ministry of Forests, Research Branch, P.O. Box 9519, Stn Prov Govt., Victoria, B.C. V8W 9C2.

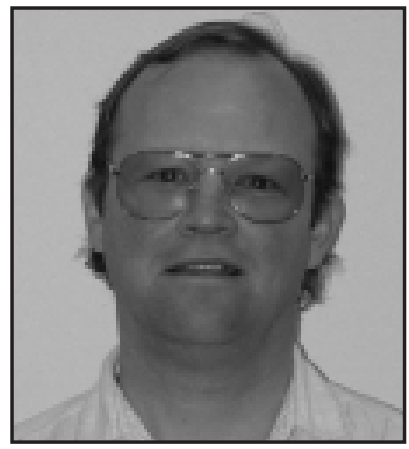

Craig Delong

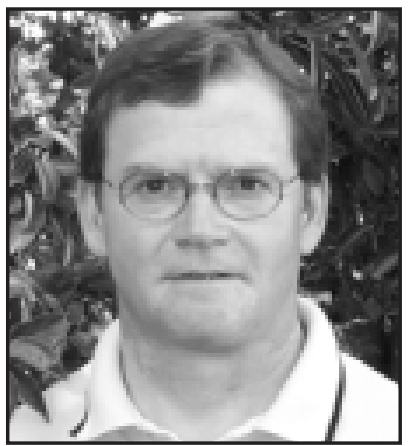

Del Meidinger
To simplify the climatic variation, we have divided the ESSF forested subzones into four groups (Very Dry, Dry, Moist and Wet) based on a regional climatic gradient that affects forest composition, structure and disturbance regime. The geographical distribution of these four groups is illustrated in Fig. 1 and the assignment of biogeoclimatic units to the groups is shown in Table 1. We compare the climate, general topography, major vegetation, and natural disturbance dynamics between these four groups. We also discuss how the differences lend themselves to different forest management practices.

\section{Climate and Topography}

The largest differences in climate between the ESSF groups are related to precipitation. Mean annual precipitation (MAP) ranges from 524-1712 $\mathrm{mm}$, with the group averages increasing from the very dry group to the wet group (Table 2). Although there is considerable variation in MAP within some 


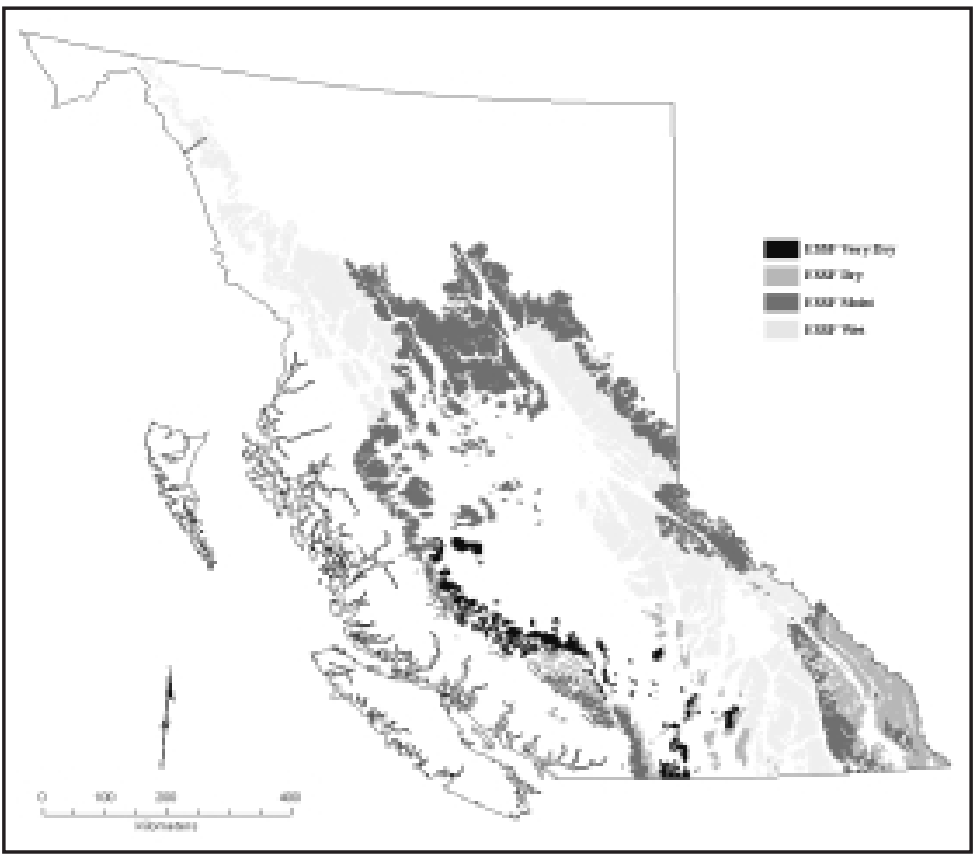

Fig. 1. Geographical distribution of four ESSF climate groups.

Table 1. Assignment of biogeoclimatic subzones to the ESSF climate groups

\begin{tabular}{lllc}
\hline Very Dry & Dry & Moist & Wet \\
\hline ESSFxc* & ESSFdm & ESSFmw & ESSFwm \\
ESSFxv & ESSFdk & ESSFmm & ESSFwk \\
& ESSFdc & ESSFmk & ESSFwc \\
& ESSFdv & ESSFmc & ESSFwv \\
& & ESSFmv & ESSFvc \\
& & & ESSFvv
\end{tabular}

*Subzone codes of two letters; first letter: $\mathrm{x}=$ very dry, $\mathrm{d}=\mathrm{dry}, \mathrm{m}=$ moist $\mathrm{w}=$ wet, $\mathrm{v}=$ very wet; second letter: $\mathrm{w}=$ warm, $\mathrm{m}=$ mild, $\mathrm{k}=$ cool, $\mathrm{c}=$ cold, $\mathrm{v}=$ very cold (see Meidinger and Pojar 1991 for more detail).

Table 2. Mean and range in mean annual precipitation (MAP) and mean seasonal precipitation (MSP) for ESSF groups

\begin{tabular}{lcc}
\hline ESSF group & & Climatic variable \\
\hline & MAP $(\mathrm{mm})$ & MSP $(\mathrm{mm})^{*}$ \\
Very Dry & $721(524-918)$ & 236 \\
Dry & $860(677-1207)$ & 303 \\
Moist & $1005(625-1995)$ & $300(257-398)$ \\
Wet & $1355(1044-1712)$ & $457(426-516)$ \\
\hline
\end{tabular}

*mean seasonal precipitation is for the time period of May 1 to September 31

of the groups, subzones within a group display similar vegetation on average sites as well as disturbance and successional patterns across the landscape. This is likely due to climatic factors other than MAP that result in similar soil moisture regime within the ESSF group.

The Very Dry ESSF group occurs in more gently sloping topography than the other ESSF groups (Table 3). The gentler relief of the Very Dry ESSF makes vegetation-damaging frosts a common feature. For example, there were up to five killing frosts (air temperature $<-4^{\circ} \mathrm{C}$ ) recorded in the month of July within one year in the Very Dry ESSF (unpublished data, B. Sagar). In contrast, data from a research trial in the Moist ESSF recorded no killing frosts over eight measurement years, including the year of the aforementioned study, in the month of July (Sagar et al. 2001).
Table 3. Proportional area of ESSF group in different slope gradient classes

\begin{tabular}{lcccc}
\hline ESSF group & \multicolumn{4}{c}{ Slope gradient (\%) } \\
\hline & $0-10$ & $10-20$ & $20-40$ & $>40$ \\
Very Dry & 37 & 32 & 23 & 8 \\
Dry & 16 & 25 & 40 & 19 \\
Moist & 24 & 30 & 36 & 10 \\
Wet & 13 & 25 & 44 & 18 \\
\hline
\end{tabular}

In the Moist and Wet ESSF, the higher proportion of steep slopes along with higher snow packs increases the probability of avalanches and snow creep.

Climate plays a key role in limiting the success of tree regeneration establishment. Low air and soil temperature are common environmental constraints to regeneration throughout the ESSF but others such as high soil moisture, snow cover duration, and growing season frost are more prevalent in certain portions of the ESSF. Climate and microclimate studies associated with silviculture systems trials such as Stathers et al. (2001) and Sagar et al. (2001) are establishing some of the climatic limiting factors for regeneration but most studies are limited to the Wet ESSF.

\section{Vegetation}

Late-successional forests throughout the ESSF zone are dominated by Engelmann spruce and subalpine fir. Lodgepole pine is common in early- to mid-successional stands, especially in the Very Dry to Moist ESSF groups. Whitebark pine (Pinus albicaulis Engelm.) and subalpine larch (Larix lyallii Parl.) are locally common in some parts of the zone. Mountain hemlock (Tsuga mertensiana (Bong.) Carrière) can be abundant in the Wet ESSF group, particularly in areas adjacent to the Mountain Hemlock zone.

Common understory vegetation throughout the forested ESSF, on mesic sites (i.e., sites of average moisture), include the shrubs white-flowered rhododendron (Rhododendron alb- 
iflorum Hook.) and black huckleberry (Vaccinium membranaceum Dougl. ex Hook.); the herbs heart-leaved arnica (Arnica cordifolia Hook.) and Sitka valerian (Valeriana sitchensis Bong.); and bryophytes Barbilophozia lycopodioides (Wallr.) Loeske, Brachythecium spp. and Dicranum spp.

In the Very Dry and Dry ESSF, grouseberry (Vaccinium scoparium Leib.) is a consistent component of the understory. Arctic lupine (Lupinus arcticus S. Wats.) and subalpine daisy (Erigeron peregrinus (Banks ex Pursh) Greene) are characteristic of mesic sites in the Very Dry ESSF.

The shrubs black gooseberry (Ribes lacustre (Pers.) Poir.) and western mountain-ash (Sorbus scopulina Greene) and herbs bunchberry (Cornus canadensis L.) and stiff clubmoss (Lycopodium annotinum L.) are common on most sites in the Moist and Wet ESSF but are only occasionally present on mesic sites in the Very Dry and Dry ESSF. Twinflower (Linnaea borealis L.) is indicative of mesic sites in the Moist ESSF while oakfern (Gymnocarpium dryopteris (L.) Newman) and threeleaved foamflower (Tiarella trifoliata L.) are indicative of mesic sites in the Wet ESSF.

\section{Natural Disturbance}

Historically, fire played a key role in shaping the temporal and spatial pattern of forests in the Very Dry and Dry ESSF forests, whereas it played an increasingly reduced role in the Moist to Wet ESSF forests. In the Very Dry ESSF forests there is evidence of some stand-maintaining fire events, where a significant proportion of the lodgepole pine canopy survives the fire resulting in a multi-aged lodgepole pine forest. However, in both the Very Dry and Dry ESSF groups, stand replacement fires, which result in an even-aged lodgepole pine forest, predominate.

Due to the infrequency of fire in the Wet ESSF, lodgepole pine is generally found only on the driest sites or not at all. Consequently, following a fire event, Engelmann spruce and subalpine fir are the only species present to provide seed to the burned area. Both these species recruit poorly after fire relative to lodgepole pine. The poorer recruiting ability of these species, combined with a short growing season and intense competition from shrub and herb vegetation results in slow sapling recruitment in young stands following fire. In the absence of stand-replacement fire, stands in the Wet ESSF are substantially affected by disturbance agents that operate in older stands, so called matrix disturbance agents (Lewis and Lindgren 2000). The disturbance agents most commonly associated with these forests are spruce beetle (Dendroctonus rufipennis Kirby), western balsam bark beetle (Dryocoetes confusus Swaine), two-year cycle budworm (Choristoneura biennis Freeman), and stem decays such as Indian paint fungus (Echinodontium tinctorium (Ellis \& Everh.) Ellis \& Everh.). These agents alter stand species composition and horizontal and vertical structure by causing tree mortality either on their own or in combination with other disturbance agents (e.g., wind). Spruce beetle may cause severe mortality at regular intervals leading to a shift in species composition from Engelmann spruce to subalpine fir and release of suppressed trees of both species (Lewis and Lindgren 2000).

Young even-aged forests originating from stand replacement fire and older multi-cohort stands with significant mortality due to matrix disturbance agents are both common in the Moist ESSF group.

The natural disturbance dynamics of the ESSF zone is relatively unknown. In particular we know very little about the action and interaction of the various disturbance agents at different spatial scales and how this changes with climatic regime. Research has been limited to landscape pattern analysis of fire (Vasbinder 2001) and detailed dendrochronological analysis of stand level disturbance (Parish et al. 1999, Antos and Parish 2002, Parish and Antos 2002) in the Wet ESSF and a landscape level dendrochronological analysis of two-year cycle budworm (Zhang and Alfaro 2002) in the Moist ESSF.

\section{Forest Management}

Small to medium sized ( $<60 \mathrm{ha}$ ) clearcuts followed by prompt regeneration with lodgepole pine and/or Engelmann spruce is the dominant silviculture system currently applied in most of the ESSF zone. A recently proposed model for forest management assumes that biodiversity can be maintained by designing forest harvesting to approximate the landscape and stand conditions created by natural disturbance (Hunter 1993, DeLong and Tanner 1996, DeLong and Kessler 2000). This paradigm would suggest a silviculture system that emulates standreplacement wildfire would predominate in the Very Dry and Dry ESSF. This paradigm would also suggest the use of silvicultural systems that emulate gap dynamics should increase proportionally from the Dry to the Wet ESSF along with the increase in natural tree mortality due to gap forming processes such as windthrow, balsam bark beetle, and two-year cycle budworm. Currently, these processes continue to persist in the relatively abundant old forest in the Wet ESSF. A recent survey by DeLong (unpublished data) indicated that at least $50 \%$ of the forests in the Wet ESSF are over 140 years old.

Recently established silvicultural systems trials at Sicamous Creek near Kamloops (Hollstedt and Vyse 1997), in the Cariboo Mountains near Williams Lake (Sutherland et al. 1992), and at Lucille Mountain near McBride (Jull and Stevenson 2001) all occur within the Moist and Wet ESSF group and are intended to compare gap-based silvicultural systems to the traditional clearcut method. These trials will provide critical information in order to assess the ability of silviculture systems to maintain function in these stands. However, maintaining abundant natural old forest is likely critical for maintaining the range of gap process functions and for providing natural disturbance baseline information to increase our understanding of these forests.

Forest management within the ESSF zone is challenging just due to the relative harshness of the climate. Making it even more challenging is the considerable ecological variability we have demonstrated, which restricts the application of new knowledge to limited portions of the zone. The ESSF groups that we describe may be a useful tool to focus research to fill obvious gaps.

\section{References}

Antos, J.A. and Parish, R. 2002. Dynamics of an old-growth, fire-initiated, sub-alpine forest in southern interior British Columbia: tree size, age, and spatial structure. Can. J. For. Res. 38: 1935-1946. Braumandl, T. and M. Eng. 2002. More accurate biogeoclimatic maps available for Cranbrook and Kootenay Lake Forest Districts. Nelson Forest Region Extension Note. B.C. Min. For., Nelson, B.C.

Coupé, R., A.C. Stewart and B.M. Wikeem. 1991. Engelmann Spruce - Subalpine Fir Zone. In D. Meidinger and J. Pojar (eds.). Ecosystems of British Columbia. pp. 223-236. Min. For., Victoria, B.C. Special Report Series 6. 
DeLong, S.C. and D. Tanner. 1996. Managing the pattern of forest harvest: lessons from wildfire. Biod. and Cons. 5: 1191-1205. DeLong, S.C. and W.B. Kessler. 2000. Ecological characteristics of mature forest remnants left by wildfire. For. Ecol. Manage. 131: 93-106.

Hollstedt, C. and A. Vyse (eds.). 1997. Sicamous Creek Silvicultural Systems Project: workshop proceedings. B.C. Min. For., Victoria, B.C. Working Paper 24.

Hunter, M.L., Jr. 1993. Natural fire regimes as spatial models for managing boreal forests. Biol. Cons. 65: 115-20.

Jull, M.J. and S.K. Stevenson. 2001. The Lucille Mountain study: 8-year results of a silviculture systems trial in the Engelmann Spruce-Subalpine Fir Zone. B.C. Min. For., Victoria, B.C. Working Paper 59.

Lewis, K.J. and B.S. Lindgren. 2000. A conceptual model of biotic disturbance ecology in the central interior of B.C.: How forest management can turn Dr. Jekyll into Mr. Hyde. For. Chron. 76: 433-443. Meidinger, D. and J. Pojar (eds.). 1991. Ecosystems of British Columbia. B.C. Min. For., Victoria, B.C. Special Report Series 6. 330 p.

Parish, R., J.A. Antos and M.-J. Fortin. 1999. Stand development in an old-growth subalpine forest in southern interior British Columbia. Can. J. For. Res. 29: 1347-1356.

Parish, R. and Antos, JA. 2002. Dynamics of an old-growth, fireinitiated, subalpine forest in southern interior British Columbia: tree-ring reconstruction of two-year cycle spruce budworm outbreaks. Can. J. For. Res. 38: 1947-1960.
Pojar, J., K. Klinka and D.V. Meidinger. 1987. Biogeoclimatic ecosystem classification in British Columbia. For. Ecol. Manage. 22: $119-154$.

Sagar, R., M. Jull and C. DeLong. 2001. Climate and Microclimate. In M.J. Jull and S.K. Stevenson. The Lucille Mountain study: 8-year results of a silviculture systems trial in the Engelmann Spruce - Subalpine Fir Zone. pp. 16-29. B.C. Min. For., Victoria, B.C. Working Paper 59.

Stathers, R.J., T. Newsome, M.J. Waterhouse and C. Sutherland. 2001. Microclimate studies on a group selection silvicultural system in a high-elevation ESSFwc3 forest in the Cariboo Forest Region. B.C. Min. For., Victoria, B.C. Working Paper 58.

Steen, O.A. and R.A. Coupé. 1997. A field guide to forest site identification and interpretation for the Cariboo Forest Region. B.C. Min. For., Land Management Handbook No. 39. Victoria, B.C. 2 Volumes. Sutherland, C., O. Steen, T. Newsome, J. Perry, P. Teti, B. Chapman and H. Armleder. 1992. Group selection system for high elevation forests (ESSFwc3) to maintain caribou habitat in the Cariboo Forest Region. Working Plan. B.C. Ministry of Forests, Williams Lake, B.C. Experimental Project 1104.02

Vasbinder, W.J. 2001. Forest fire in the mountain ranges of northeastern British Columbia: A historical perspective. MSc. thesis. University of Northern B.C., Prince George, B.C., 134 p.

Zhang, Q. and R.I. Alfaro. 2002. Periodicity of two-year cycle spruce budworm outbreaks in Central British Columbia: a dendro-ecological analysis. Forest Science 48: 722-731. 